structure - cognitive, affective and behavioral components. Based on the well-known studies a theoretical model was developed for studying the problem of subjective well-being for homosexuals.

Formulation of the problem. The progress of socio-political transformations of domestic society has actualized many problems, in particular plurality, tolerance as a way of coexistence of social groups of different genesis and subject orientation. Among them, new communities, such as the virtual, or community of non-traditional sexual orientation, such as homosexuality, take on the prominent place. The problem of its integration into society is associated with a change in the value determinants of coexistence of people both in the intergroup dimension and in the intragroup. Therefore, the problem of criteria, indicators, welfare of the homosexual person is relevant at the time.

Consequently, the problem of subjective well-being is relevant at the time and is sufficiently thoroughly presented in the work of scientists $(O$. Danilchenko, etc.). However, subjective well-being of not only individuals, but also groups of individuals, in particular homosexuals, in the context of their assessment of their own lives is not sufficiently developed, which led to the choice of the topic of research.

Key words: subjective well-being, homosexual personality, hedonistic approach, eudemonic approach, components, evaluation, life satisfaction, emotional comfort

УДК159.944.4:305]:629.7(045)

І. В. КАРЯКА

DOI: https://doi.org/10.35619/prap_rv.vi12.56

\title{
ГЕНДЕРНІ ОЗНАКИ ПРОЯВУ СТРЕСОСТІЙКОСТІ ПРАЦІВНИКІВ АВІАЦІЙНИХ ОРГАНІЗАЦІЙ
}

Стаття присвячена вивченню особливостей стресостійкості людини, щзо детермінується гендерною приналежністю індивіда та визначає структурну організацію і змістовне наповнення ії професійної діяльності. В рамках означеної проблематики здійснено теоретичний аналіз вивчення стресостійкості фахівців авіаційної галузі за гендерною приналежністю, а також представлено програму емпіричного дослідження щодо виявлення даного феномену психічної діяльності людини, проаналізовано та інтерпретовано отримані результати та визначено перспективні напрямки його вивчення.

Ключові слова: стресостійкість, стрес, адаптивність, тривожність, гендер, стать, детермінанти стресостійкості.

Статья посвящена изучению особенностей стрессоустойчивости человека, детерминируется гендерной принадлежсностью индивида и определяет структурную организачию и содержательное наполнение ее профессиональной деятельности. B рамках обозначенной проблематики осуществлен теоретический анализ изучения стрессоустойчивости специалистов авиационной отрасли по гендерному принадлежности, а также представлена программа эмпирического исследования по выявлению данного феномена психической деятельности человека, проанализированы и интерпретированы полученные результаты и определены перспективные направления его изучения.

Ключевые слова: стрессоустойчивость, стресс, адаптивность, тревожность, гендер, пол, детерминанты стрессоустойчивости.

Постановка проблеми. Стрімкий розвиток життя сучасної людини ставить перед нею все нові і нові завдання, вирішення яких потребує швидкого і продуктивного реагування щодо подолання проблемних ситуацій у професійній сфері іiі життєдіяльності. Дослідження стресостійкості усвідомлюється науковцями багатьох наукових галузей (фізіології, соціології, охороні праці, теоретичній та прикладній психології) як гостро актуальна проблема сучасного суспільства, оскільки різноманітні реакції людини під час переживання стресу не завжди відповідають очікуванням та сподіванням інших. Саме тому погляди багатьох психологів спрямовані на виявлення раціонального компоненту в організації стресостійкості.

Аналіз останніх досліджень і публікацій. У науковій літературі налічується значне розмаїття трактування поняття стресостійкості. Так, у психологічному словнику дана дефініція визначається як здатність людини адекватно переносити напружену або нестандартну ситуацію, не занурюючись у стан стресу [4].

В свою чергу, російський психолог та психофізіолог В. О. Бодров розглядає даний феномен людської психіки як інтегральну психічну якість особистості, яка характеризується необхідним ступенем адаптації індивіда до екстремальних ситуацій і негативних факторів професійної діяльності. 
Це говорить про те, що стійкість людини до стресу детермінується іiї рівнем активації ресурсів організму і психіки особистості та проявляється в її функціональних станах та працездатності [3].

На думку соціолога П. Б. Зільбермана, стресостійкість постає інтегративною властивістю особистості, яка характеризується взаємодією емоційного, інтелектуального та мотиваційного компонентів психічної діяльності індивіда, що забезпечують оптимально успішне досягнення цілей діяльності складних емоційних обставинах [6].

Сучасний представник педагогічної галузі Н. І. Бережна визначає стресостійкість як особистісну якість людини, що поєднує в собі психофізіологічну, мотиваційну, інтелектуальну, емоційно-вольову та професійну складову [2]. Фахівець інженерної психології, Е. А. Мілерян, висвітлює проблему стійкості до психологічних навантажень, як емоційну стійкість і здатність контролювати емоції [7]. Психофізіолог Н.М. Данилова під стресостійкістю вбачає здатність вирішувати великі навантаження й успішно вирішувати завдання в екстремальних ситуаціях [5]. Проведений аналіз наукової літератури дозволяє стверджувати те, що особливості прояву гендерних аспектів стресостійкості фахівців авіаційної галузі знаходиться у руслі загально-психологічних проблем та визначається нами як здатність людини адекватно реагувати на стресори, що обумовлюється статевою приналежністю.

Відповідно до цього дана властивість людини має здатність забезпечувати високу ефективність діяльності і зберігати здоров'я людини. Відтак, стресостійкість забезпечує високу ефективність діяльності та сприяє збереженню здоров'я людини. Особливо це стосується працівників авіаційних організацій, де посадові обов'язки будь-якої посади носить досить напружений характер і призводить до значного нервопсихічного напруження, що викликає складні фізіологічні зміни в організмі фахівця та призводить до появи стресу. Саме тому вивчення гендерних особливостей прояву стресостійкості в професійній діяльності працівників авіаційних організацій постає нагальною проблемою в психології сьогодення.

Формування цілей статті. Мета статті полягає у виявлення гендерних особливостей прояву стресостійкості фахівців авіаційної галузі.

Виклад основного матеріалу і результати дослідження. В рамках вивчення проблематики нашого дослідження було виявлено той факт, що функціонування стресостійкості охоплює ряд сфер психічної діяльності людини: психофізіологічний, вольовий, мотиваційний, емоційний, інтелектуальний, та пізнавальний. Так, психофізіологічний включає в себе особливості будови нервової системи і протікання нервових процесів, біологічні ознаки, статеві особливості, що обумовлює швидкість, яскравість, інтенсивність поведінки людини у стресовій ситуації. В свою чергу вольовий прояв стресостійкості дає можливість здійснювати свідому регуляцію власних дій під дією стресу [1].

Мотиваційний компонент відображає спрямованість особистості до виконання поставленого завдання перед людиною та характеризується здатністю людини ставити перед собою завдання i виконувати їх, витримуючи психологічні навантаження. Даний прояв виконує спонукальну та регулятивну функцію стресостійкості. Емоційні прояви стресостійкості полягають у сприйнятті ситуації на почуттєвому рівні та можливості керувати власними емоціями, якість яких цілком залежить від емоційного досвіду людини щодо подолання негативного впливу стресогенних ситуацій. Інтелектуальний прояв стресостійкості виражається в здатності правильно оцінювати ситуацію, у вмінні підбирати адекватні стилі поведінки у екстремальних ситуаціях, можливості здійснити прогнозування змін ситуації, тощо. Він поєднує в собі тип мислення і розумові здібності. Саме дані особливості дають змогу людині сформувати ставлення до стресогенної ситуації і знайти спосіб ії вирішення [1]. Пізнавальний прояв характеризує ступінь осмислення та розуміння власних потенційних можливостей щодо подолання різних негативних наслідків стресу, способів профілактики появи стресу, пошуку нових конструктивних способів вирішення стресогенних ситуацій, тощо [3].

Зазначені вище прояви стресостійкості залежать від ряду психофізіологічних властивостей, де основним фактором виступає статево-рольова приналежність. Враховуючи вказане, слід зауважити, що стійкість до дій стресових факторів у фахівців авіаційної галузі виступає професійною якістю, оскільки працівники даної галузі мають підвищений ризик до впливу негативних факторів праці: важкі умови роботи, високі вимоги до особистості фахівця, екстремальні ситуації, проблеми комунікативної взаємодії, організаційні проблеми та інформаційне перенавантаження. Все це обумовлює наявність у працівників достатнього рівня розвитку стійкості до стресів. Відповідно до цього, можна сказати, що існує численна кількість чинників та детермінант стресостійкості, а також факторів що гальмують появ стресостійкості. Фахівці авіаційної галузі часто потрапляють під їх вплив. Проте, основним в дослідженні стресостійкості фахівців авіаційної сфери $є$ розгляд та 
дослідження даних детермінант у зв'язку з гендерними аспектами та особливостями професійної діяльності.

Серед зазначених детермінант особливої уваги, стосовно вивчення гендерних особливостей стресостійкості у фахівців авіаційної галузі, набуває компонент емоційної стабільності у чоловіків і жінок даної професії, оскільки саме цей аспект психічної діяльності людини регулює відношення індивіда до стресових ситуацій та обумовлює вибір стратегій поведінки під час його переживання.

Відтак, значний вплив на розвиток стійкості до стресу фахівців авіаційної галузі має рівень тривожності особистості, що виявляється в схильності особи до хвилювання, наростанням рівня напруги в ситуаціях, які можуть негативно впливати на професійну та особистісну сферу життєдіяльності людини. Саме тому, дослідження тривожності при вивченні рівня стресостійкості $\epsilon$ важливим аспектом розгляду індивідуальних особливостей адаптації до стресу. Характеризуючи особливості розвитку стресостійкості у чоловіків та жінок, можна помітити, що вони по-різному переживають стресогенні події. Чоловіки $\epsilon$ більш закритими від зовнішнього світу, інтровертованими, неекспресивними, тому схильні до накопичування стресогенних подій, що в свою чергу, знижує рівень стресостійкості. Жінки ж, навпаки, схильні більше виражати свої емоції, тому рівень їх стресостійкості, як правило, значно вищий. Відповідно до гендерного типу особистості, тобто психологічної статі, ці явища можуть мати інший характер,наприклад, у ремінних чоловіків спостерігається більша експресивність, ніж у маскулінних чоловіків, тому вони схильні мати вищий рівень стресостійкості. Важливим аспектом $є$ розгляд взаємозв'язку рівня стресостійкості у різних гендерних типів і рівня тривожності, адже дана індивідуальна властивість більшою мірою впливає на рівень супротиву стресогенним факторам. Вона $\epsilon$ інтегральним явищем, рисою характеру, яка тісно пов'язана з емоційною сферою особистості, а отже, і з гендерною приналежністю.

У працівників авіаційних організацій, гендерний розподіл в рівні стресостійкості та особливості прояву тривожності, можуть мати свої особливості, оскільки, як правило, для технічної сфери характерний особливий розподіл гендерних типів (наприклад, наявність андрогенних i маскулінних жінок), що обумовлено особливостями діяльності даної галузі.

Отже, особливості гендерного розподілу в рівні стресостійкості та його зв'язок 3 індивідуальними особливостями особистості значно впливають на рівень опору стресу індивіда. Особливе значення дане явище має саме для працівників авіаційної галузі. Враховуючи все вище сказане, нами було обрано основний напрям дослідження, який включав в себе виявлення особливостей стресостійкості чоловіків і жінок за гендерною приналежністю, де основною особливістю, за якою буде здійснено аналіз особливостей, було обрано індивідуально-психологічну особливість - тривожність. Отримані результати статево-рольового опитувальника С.Бем дають можливість констатувати той факт, що серед фахівців авіаційної галузі чоловічої статі $80 \%$ досліджуваних $\epsilon$ андрогенними, і лише $20 \%$ - маскулінними. Серед жінок було виявлено $60 \%$ представників андрогенного, та 40\% фемінного типу. Показників фемінності у чоловіків та маскулінності у жінок виявлено не було. Графічне зображення отриманих результатів представлене на рисунку 1.
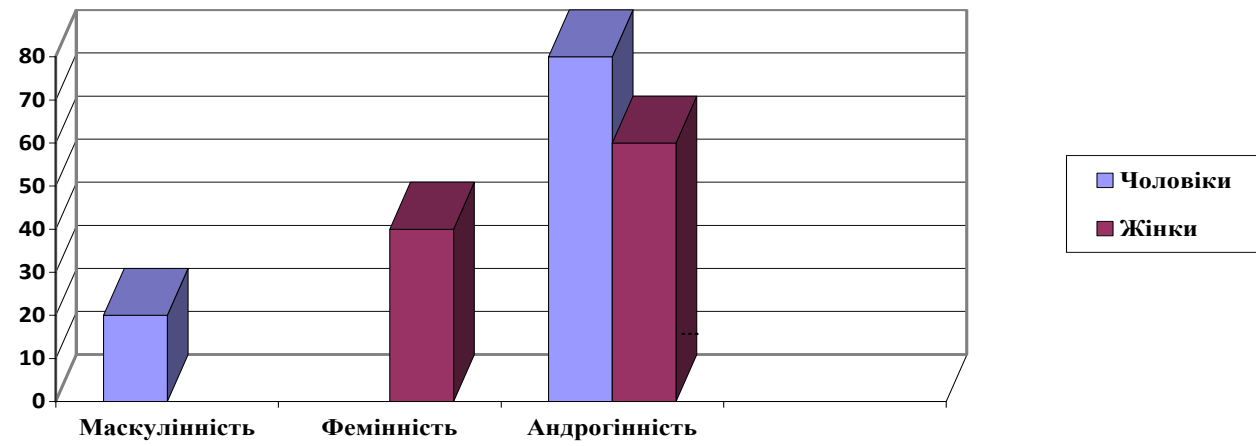

Рис. 1. Результати статево-рольового опитувальника С. Бем

За результатами методики діагностики стресостійкості та соціальної адаптації Холмса і Раге в адаптації Н.Є. Водоп'янової було виявлено той факт, що представник андрогенної статі 16,7\% жінок і $12,5 \%$ чоловіків мають низький рівень стресостійкості; $16,7 \%$ жінок і $50 \%$ чоловіків - середній і $66,6 \%$ жінок і 37,5\% чоловіків - високий рівень стресостійкості. Високий рівень стресостійкості було також виявлено у 100\% фемінних жінок. Низький рівень стресостійкості було виявлено у 100\% маскулінних чоловіків. Кількісні показники даної методики подано в таблиці 1. 
Таблиия 1.

\section{Рівень розвитку стресостійкості та соціальної адаптації працівників авіаційних організацій за гендерною приналежністю}

\begin{tabular}{|l|c|c|c|c|}
\hline \multirow{2}{*}{$\begin{array}{l}\text { Рівень стійкості до } \\
\text { стресу }\end{array}$} & \multicolumn{2}{|c|}{ Чоловіки } & \multicolumn{2}{c|}{ Жінки } \\
\cline { 2 - 5 } & андрогінні & маскулінні & андрогінні & фемінні \\
\hline високий & $37,5 \%$ & - & $16,7 \%$ & $100 \%$ \\
\hline середній & $50 \%$ & - & $16,7 \%$ & - \\
\hline низький & $12,5 \%$ & $100 \%$ & $66,6 \%$ & - \\
\hline
\end{tabular}

Отримані показники рівня стресостійкості засвідчують той факт, що андрогенним чоловікам та жінкам притаманні усі рівні їі розвитку. В свою чергу, фемінні жінки та маскулінні чоловіки схильні виявляти крайні показники рівня розвитку стресостійкості. На нашу думку, дане явище обумовлюється саме гендерною приналежністю. Так, представникам маскулінного типу досить важко переживати стресові події, оскільки за своєю природою вони наділені більш жорсткими рисами характеру, їм притаманна агресивність, егоцентризм, лідерство. Водночас фемінний тип є більш стриманим та покірним, тому стресові події не так сильно впливають на нього. Люди андрогенного типу наділені як фемінними, так і маскулінними рисами, тому у даному випадку на рівень стресостійкості можуть впливати наявні маскулінні, або фемінні риси.

Діагностика рівня тривожності за методикою вимірювання рівня тривожності Ф. Тейлора, в адаптації Т. А. Немчинова, було виявлено, що 16,7\% андрогенних жінок мають високий, $33,3 \%$ середній і $50 \%$ з низький рівень прояву тривожності. 75\% фемінних жінок мають середній рівень тривожності і 15\% - високий. Щодо андрогенних чоловіків, то: $12,5 \%$ показали високий і $87,5 \%$ середній рівень тривожності. В свою чергу, $100 \%$ маскулінних чоловіків мають високий рівень тривожності. Отримані результати даної методики подано в таблиці 2.

Показники даної таблиці вказують на те, що маскулінні чоловіки є більш тривожними ніж андрогенні, і навпаки, фемінні жінки є більш тривожними ніж андрогенні жінки. На нашу думку дане явище пояснюється тим, що високий рівень тривожності у маскулінних чоловіків є проекцією суб'єктивних переживань, що виникають у наслідок виконання чоловіком соціальної ролі. Низький рівень тривожності у фемінних жінок також викликається її взаємозв'язком 3 виконуваною соціальною роллю, а також більшою екстравертованістю та, у більшості випадків, можливістю дати вихід емоціям.

Таблиия 2.

Рівень розвитку тривожності працівників авіаційної галузі за гендерною приналежністю

\begin{tabular}{|l|c|c|c|c|}
\hline \multirow{2}{*}{\begin{tabular}{l} 
Рівень стійкості \\
\cline { 2 - 5 }
\end{tabular}} & \multicolumn{4}{|c|}{ ктількісні показники (у\%) } \\
\cline { 2 - 5 } & андрогінні & маскулінні & андрогінні & жемінні \\
\hline \multirow{2}{*}{ високий } & 12,5 & 100 & 16,7 & - \\
\hline середній & 87,5 & - & 33,3 & 75,0 \\
\hline низький & - & - & 50,0 & 15,0 \\
\hline
\end{tabular}

Все це говорить про те, що гендерна та статева приналежність, рівень стресостійкості, а також рівень тривожності працівників авіаційної галузі невід'ємно пов'язані один від одного. Рівень стресостійкості та тривожності мають особливий розподіл серед представників різних гендерних типів працівників авіаційної сфери, а це в свою чергу, є особливістю прояву даного явища. Застосування статистичного U-критерію Манна-Уітні дає можливість констатувати той факт, що формування, розвиток та функціонування стресостійкості працівників авіаційних організацій детермінується гендерною приналежністю кожного з них. Відтак, андрогінні та фемінні жінки схильні проявляти в більшій мірі врівноваженість, що робить їх більш стійкими до стресів. В свою чергу, андрогінні та маскулінні чоловіки $є$ більш вразливими та не здатними протистояти емоційним навантаженням.

Отримані результати дослідження дозволили нам розробити практичні рекомендації щодо підвищення рівня стресостійкості у працівників авіаційних організацій за різними напрямками: 
- організаційний: правильний підбір та розстановка кадрів; постановка конкретних завдань для персоналу; проектування робіт; взаємодія між керівником та персоналом; використання програм оздоровлення працівників.

індивідуальний: навчання навичкам аутогенного тренування; застосування методів релаксації; дихальна гімнастика; регуляція режиму відпочинку та праці; застосування технік візуалізації.

керівний: раціоналізація процесів праці; удосконалення засобів праці; розробка оптимальних режимів праці та відпочинку; створення сприятливого соціально-психологічного клімату в колективі.

Висновки та перспективи подальших розвідок Аналіз результатів дослідження дозволяє констатувати той факт, що стресостійкість детермінується гендерною приналежністю індивіда, яка, я свою чергу, обумовлює рівень тривожності у фахівців авіаційної галузі.

Аналіз стресостійкості чоловіків та жінок, працівників авіаційної сфери дозволяє зробити висновок про те, що фемінні жінки краще адаптуються до стресогенних умов життедіяльності та праці, ніж маскулінні чоловіки, проте андрогінні чоловіки та жінки адаптуються приблизно на однаковому рівні, що пов'язано з особливостями даного типу і тим, що він характеризується наявністю як типово жіночих, так типово чоловічих рис, що допомагає людям краще долати стресові події.

Аналіз тривожності показує на скільки дана особливість $є$ важливою для розподілу стресостійкості за гендерною приналежністю, адже у чоловіків, що належать до маскулінного типу, наявні високі показники тривожності та низькі стресостійкості, у фемінних жінок можна побачити високі показники стресостійкості та низькі тривожності, у андрогенних чоловіків та жінок також ці характеристики взаємопов'язані.

Проведене дослідження не вичерпує усіх аспектів гендерних особливостей прояву стресостійкості фахівців авіаційної галузі, де перспективним доповненням здійснення наукових розвідок вважаємо, вивчення рівня тривожності та самооцінки власних можливостей адаптації до стресу, оскільки можна припустити, що чим рівень тривожності залежить від рівня самооцінки власних можливостей робітників авіаційної галузі.

\section{Список використаних джерел}

1. Апчел В. Я. Стресс и стрессоустойчивость человека / В. Я. Апчел, В. Н. Цыган. - СПб., 1999. $-86 \mathrm{c}$.

2. Бережная Н. И. Стрессоустойчивость оперативных сотрудников таможенных органов / Н. И. Бережная // Ежегодник Рос. Психол. Об-ва : материалы 3 съезда психологов, 25-28 июня 2003 г. - СПб. : Изд-во С.-Петерб. ун-та, 2003. - Т. 1. - С. 453-457.

3. Бодров В. А. Информационный стресс : учеб. пособ. для вузов / В. А. Бодров. - М. : ПЕР СЭ, 2000. $-352 \mathrm{c}$.

4. Войтко В. І. Психологічний словник / В. І. Войтко. - Київ : Вища шк., 1982. - 218 с.

5. Данилова Н. Н. Функциональные состояния: механизмы и диагностика / Н. Н. Данилова. М. : МГУ, 1985. -287 c.

6. Зильберман П. Б. Эмоциональная устойчивость и стресс / П. Б. Зильберман. - Пермь, 1973. - C. $13-15$.

7. Милерян Е. А. Эмоционально-волевые компоненты надежности оператора / Е. А. Милерян // Очерки психологии труда операторов / Е. А. Милерян. - М. : Наука, 1974. - С. 5-82.

\section{References} $-86 \mathrm{~s}$.

1. Apchel V. Ja. Stress i stressoustojchivost' cheloveka / V. Ja. Apchel, V. N. Cygan. - SPb., 1999.

2. Berezhna N. I. Stressoustojchivost' operativnyh sotrudnikov tamozhennyh organov / N. I. Berezhnaja // Ezhegodnik Ros. Psihol. Ob-va : materialy 3 s'ezda psihologov, 25-28 ijunja 2003 g. SPb. : Izd-vo S.-Peterb. un-ta, 2003. - T. 1. - S. 453-457.

3. Bodrov V. A. Informacionnyj stress : ucheb. posob. dlja vuzov / V. A. Bodrov. - M. : PER SJe, 2000. $-352 \mathrm{~s}$.

4. Vojtko V. I. Psy`xologichny`j slovny`k/ V. I. Vojtko. - Ky`yiv : Vy`shha shk., 1982. - 218 s.

5. Danilova N. N. Funkcional'nye sostojanija: mehanizmy i diagnostika / N. N. Danilova. - M. : MGU, 1985. $-287 \mathrm{~s}$.

6. Zil'berman P. B. Jemocional'naja ustojchivost' i stress / P. B. Zil'berman. - Perm', 1973. - S. 1315. 
7. Milerjan E. A. Jemocional'no-volevye komponenty nadezhnosti operatora / E. A. Milerjan // Ocherki psihologii truda operatorov / E. A. Milerjan. - M. : Nauka, 1974. - S. 5-82.

\section{V. Kariaka GENDER BASED SIGNS OF STRESS MANAGEMENT MANIFESTATION AT THE EMPLOYEES OF AVIATION ORGANIZATIONS}

In the article it has been considered psychological aspects of studying of gender based signs of manifestation of the stress management at aviation area employees. Theoretical examination of the mentioned issue indicates to the fact that functioning of the stress management is determined by a number of constructs of human mental activity. To the later belong: strong-willed, motivational, emotional, intellectual and cognitive skills of individual.

As the formation and development of the above-mentioned components of the stress management are conditioned by psychophysical possibilities of an individual, that is why one of factors that influences on the manifestation of the present phenomenon is the gender based belonging of an individual. This fact should be taken into account as to the professional activity of aviation area specialists as the presence at the employees of this area of high level of stress management is a guarantee of productivity and performance of their professional obligations fulfillment.

As a result of carried out experiment, it has been noted that feminine women adapt better to stressogenic life and work conditions that masculine men, however androgenic men and women adapt at approximately the same level which is related to the particularities of this kind and to the fact that it is characterized by the presence of typically women's and typically men's features what helps better to humans to overcome stress events. Identified particularities don't exhaust all aspects of their studying and contribute to the research of new forms of explanation.

Key words: stress management, stress, adaptability, anxiety, gender, sex, stress management determinants.

УДК 159.922

В. В. КИРИЧЕНКО

DOI: https://doi.org/10.35619/prap_rv.vi12.57

\section{ІНВАРІАНТНА МОДЕЛЬ ФАХОВИХ КОМПЕТЕНТНОСТЕЙ ДЕРЖАВНОГО СЛУЖБОВцЯ}

У статті представлені результати теоретичного дослідження, виконаного в рамках проекту «Оиінювання ринку управлінських державних послуг та функціональної й компетентнісної спроможності державної служби та держслужбовців в Україні». Нами була обтрунтована інваріантна модель професійної компетентності державного службовия, описано базові інваріанти та створено методику оцінки компетентнісної спроможності. Визначено провідні професійні та особистісні компетентності, які пов'язані з аналізом та обробкою інформаиії. До базових інваріантів професійної діяльності державного службовия ми відносимо ті професійні компетениії, які реалізуються у типових ситуаціях виробничої взаємодї та є мінімально-достатніми для виконання професійної діяльності.

Ключові слова: професійна діяльність, держсавна служба, інваріанти професійної діяльності, компетениія, інформачійна культура

В статье представлены результаты теоретического исследования, выполненного в рамках проекта «Оиенка рынка управленческих государственных услуг и функциональной $u$ компетентностной способности государственной служббы и госслужащих в Украине». Нами была обоснована инвариантная модель профессиональной компетентности государственного служащего, описано базовые инварианты и создана методика оценки компетентностной способности. Определены ведущие профессиональные и личностные компетенции, связанные с анализом и обработкой информачии. $K$ базовым инвариантам профессиональной деятельности государственного служащего мы относим те профессиональные компетенции, которые реализуются в типичных ситуачиях производственного взаимодействия и является минимально достаточныли для выполнения профессиональной деятельности.

Ключевые слова: профессиональная деятельность, государственная служба, инварианть профессиональной деятельности, компетенция, информационная культура

Постановка проблеми. У XX столітті відбулася кардинальна зміна у системі відносин особистості та держави (у якості осіб, які виконують державні функції). Держава існує для людей, а Випуск 12, 2019. Збірник наукових праць РДГУ 